\title{
Employment effects of business dynamics: Mice, Gazelles and Elephants
}

\author{
Zoltan J. Acs · Pamela Mueller
}

Received: 21 September 2006/Accepted: 22 February 2007/Published online: 5 June 2007

(C) Springer Science+Business Media B.V. 2007

\begin{abstract}
Much of the theoretical work on industry dynamics focuses on the role of 'noisy' selection and incomplete information on firm entry and survival. We extend this research by looking at the impact of firm heterogeneity on employment effects for 320 U.S. Metropolitan Statistical Areas (MSA). We find that only start-ups with greater than 20 and less than 500 employees have persistent employment effects over time and only in large diversified metropolitan regions. Therefore, both the type of entry (Gazelles) and the characteristics of the region are important for employment growth.
\end{abstract}

Keywords Business dynamics $\cdot$ New business formation · Gazelles · Regions

JEL Classification J6 $\cdot$ L6 $\cdot$ L8 $\cdot$ M13 $\cdot$ L26

\section{Introduction}

New (small) business formation burst into the news in the early 1980's in large part because of the

Z. J. Acs · P. Mueller $(\bowtie)$

Entrepreneurship, Growth and Public Policy,

Max Planck Institute of Economics,

Kahlaische Strasse 10, Jena 07745, Germany

e-mail: pmueller@econ.mpg.de research conducted by one individual-David Birch. Birch put together an extremely innovative and potentially powerful database. For years Dun and Bradstreet has collected data on firms and establishments in the U.S. economy. Vendors could obtain credit and financial information on companies to which they were selling on credit. Businesses such as marketing firms could also use the data collected by Dun and Bradstreet to identify potential customers. Birch, who was affiliated with MIT's Center for the Study of Neighborhood and Regional Change, used the data to study the dynamics of business and employment effects in the U.S. By linking the data on establishments to parent firms, the data enabled him to identify the birth, death and growth of establishments and to analyze establishments of different sizes and longevity (Birch 1981). ${ }^{1}$

Birch made two seminal contributions, which have, unfortunately, been often overlooked, in the subsequent controversy over his methods and conclusions (Davis et al. 1996b). First, he pieced together an extremely rich and powerful dataset that allowed researchers, for the first time, to study

\footnotetext{
${ }^{1}$ One must also be aware of the sever limits of credit bureau data. Two issues stand out: first, the data has a long lag period before all new firms are incorporated into the database; second, credit bureaus have no interest in collecting data on establishments of existing firms since in most cases they do not need a credit report.
} 
business dynamics for the full spectrum of business and industries in the U.S. Until then, economists had been content studying highly aggregated government data that masked the birth, death and growth of businesses.

Birch's second major contribution is his systematic study of small businesses, which stimulated research and debate on small firms. Few economists had studied small business in the U.S. economy before Birch even though these businesses constituted a large fraction of employment and sales in the economy (Brock and Evans 1989). One interesting aspect of his work focuses on the classification of different types (age and size) of establishments. "Of all the net new jobs created in our sample of 5.6 million businesses between 1969 and 1976, twothirds were created by firms with twenty or fewer employees (Birch 1981, p. 7).' He goes on to say, "Another distinguishing characteristic of job replacers is their youth. About 80 percent of the replacement jobs are created by establishments four years old or younger.' Finally, "Whatever they are doing, however, large firms are no longer the major providers of new jobs for Americans (Birch 1981, p. 8).' Today we know that small businesses do not generate the vast majority of jobs. However, they do produce a greater number of jobs than we would expect based on their share of employment (Haltiwanger 2006).

Today, there are better datasets available for studying business dynamics, for example the Linked Census of Manufacturing data (Dunne et al. 1989) and The Longitudinal Research Database (Davis et al. 1996a). The Bureau of the Census Longitudinal Business Database (LBD) provides longitudinal business data with information on employment payroll, industry and geography from 1975 to 2001 for establishments and firms with at least one employee (Jarmin and Miranda 2002). A precursor to the LBD is the Longitudinal Establishment and Enterprise Microdata (LEEM) jointly developed by the U.S. Bureau of the Census and the U. S. Small Business Administration (Acs and Armington 1998).

We now know that the real issue in business dynamics is not so much size but age. Most new firms are small. Most new plants are often larger than new independent firms and their parent firm is large most of the time (Armington and Acs 2004). However, we do not know as much about the rapidly growing business that started out larger than new firm but smaller than establishments of large firms. These so called gazelles, new rapidly growing firms, represent the most dynamic sector of the economy. The purpose of this paper is to examine the employment effects of business dynamics in a regional context. Employment effects are similar to persistence of jobs. However, while employment persistence looks at how long the job lasts, a form of survival, employment effects focus on surviving firm employment. Employment effects have three aspects. First, they examine the impact of employment creation by firm ${ }_{j}$

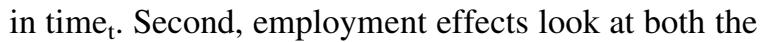
creation of new jobs as well as the displacement of existing jobs. Third, employment effects study the path of employment created by firm $\mathrm{j}_{\mathrm{j}}$ over time. Fritsch and Mueller $(2004,2007)$ and Mueller et al. (2007) found employment effect to first, increase employment directly (employment creation in entry cohorts), second to crowd out inefficient incumbents lowering employment (as well as shrinking and exit of the entrants), and third to challenge incumbents leading to an increase in employment in these incumbent businesses.

While the theoretical literature suggests that noise selection plays an important role in industry dynamics it does not give a lot of insight into what role different types of entrants play. In other words, what is the impact on employment five years from now of new firms, rapidly growing firms and plants that entered today? In this vein we revisit a question raised by David Birch thirty some years ago "Who Creates Jobs: Mice, Gazelles or Elephants?" The most interesting insight of Birch was that it was the mostly new rapidly growing firms which were responsible for most of the employment growth in regional economies. Given the very important difference between small firms with less than 20 employees (Mice) and large firms with more than 500 employees (Elephants) we take a more careful look at these high potential firms (Gazelles) and Gazelle regions in this paper.

The next section of this paper presents the theoretical framework for understanding the relationship between business dynamics and employment effects. The third section presents data and measurement issues. The forth section presents the empirical 
results over time and the fifth section examines regions with a high concentration of rapidly growing establishments in detail. The final section offers a summary and conclusions.

\section{The relationship between business dynamics and employment effects}

The literature and issues focusing on gross employment dynamics are important. While this research has a long tradition, it is only in the last decade that economists have 'picked the lock' of numerous census bureaus and organized the primary economic census data so that the births, deaths, survival and growth of individual business units can be traced. ${ }^{2}$

This research has born the fruit of a great outpouring of stylized facts, where no more than impressions had existed before. However, the interpretation of these facts is less clear. While the importance of research on employment dynamics is manifest to the economy, its development has not been theory driven. In fact, figuring out which theoretical models the stylized facts shed light on "is itself an exercise in hunting and gathering", (Caves 1998, p. 1947). ${ }^{3}$ This empirical literature can be interpreted through the lens of dynamics models and theories of industrial evolution. Therefore, it should be of importance to evolutionary economists who have developed models of industry evolution to better understand underlying patterns of gross employment flows (Katsoulacos 1994, Dopfer 1995).

A firm's underlying efficiency level cannot be directly observed but is learned over time through the process of production. A firm that accumulates favorable information about its efficiency expands and survives, whereas a firm that accumulates sufficiently unfavorable information exits. Firms differ in size over time not because of capital intensity, but because some learn that they are more efficient than others. In this model, firms and potential entrants know the entire equilibrium price sequence, and based on it, they make entry, production, and exit decisions. A one-time entry cost is borne at the time of entry. Thereafter, only produc-

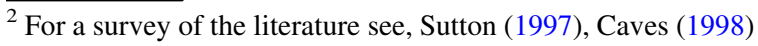
Davis and Haltiwanger (1999).

${ }^{3}$ Pakes and Ericson (1995) and Camerer and Lovallo (1999).
}

tion cost are incurred, where efficient firms grow and survive and the inefficient decline and close (Jovanovic 1982).

The stochastic outcomes of an individual firm's investment, coupled with competitor investment outcomes determine the probability distribution over future profitability streams. A plant's investment outcome may improve its position relative to competitors, thus leading to expansion, or it may involve a relative deterioration, thus leading to contraction and possibly exit. Investment in the model thus entails elements of active learning and selection. This model builds in an explanation for perpetual entry and exit and develops a theory of firm and industry dynamics in which investment outcome involves idiosyncratic uncertainty. Hence, the active learning theory embeds technical change into a rich model of firm-level heterogeneity and selection (Pakes and Ericson 1998)

Differences in initial conditions, or uncertainties about future conditions, that leads firms to commit to different factor intensities and production techniques. These differences in turn lead to heterogeneity in firm-level responses to common cost and demand shocks (Lambson 1991). Even firms that produce identical products with identical technologies can face idiosyncratic cost disturbances. For example, energy costs and tax burdens are often heavily influenced by local conditions. Exogenous, idiosyncratic cost disturbances lead to contraction at some firms and simultaneously, expansion at other firms (Hopenhayn 1992). The above theories account for several factors that would plausibly account for employment dynamics within narrowly defined sectors of the economy or regions.

These models all suggest that the enduring differences in the size distribution of firms and firm growth rates result less from the effects of capital intensity than from the effects of "noisy" selection and incomplete information. If this is the case, then the persistence of employment growth in the service sector should not be substantially different from the more capital-intensive manufacturing sector (Lucas 1978; Lucas and Prescott 1971). Differences in employment growth should not be different between regions based on different industry mix.

Much of the empirical analysis in recent studies of firm-level and plant-level employment dynamics is explicitly couched in terms of this type of theory 
(Evans 1987; Dunne et al. 1989). Davis and Haltiwanger (1992), looking at gross employment flows for the period 1978-1983, found that learning and initial conditions provide a plausible explanation for the strong and pervasive relationship between job reallocation rates and plant age. These results lead to the conclusion that passive learning stories are quite useful for interpreting variations in job reallocation intensity across different types of plants and manufacturing industries.

While interesting as a way to think about business dynamics, these models do not predict patterns of employment creation. They do not account for differences across sectors of the economy, such as services and manufacturing, firm heterogeneity, types of business startups and regions. However, it would follow from these dynamic models that if learning and noisy selection are more important than capital intensity, business dynamics should be similar for sectors with substantially different capital intensity, other things being constant. If capital intensity is more important then learning and selection, capital-intensive sectors should have higher persistence rates than less capital-intensive sectors because of sunk costs. Acs and Audretsch (1989a and 1989b) found that even small firms are not significantly deterred from entering industries that are relatively capital intensive. Of course, one could easily imagine a noisy selection process with different entry fees and different means and variances of the efficiency parameters across sectors. This could generate very different employment dynamics patterns.

There are several limitations to the interpretation of the employment dynamics literature through the lens of industrial dynamics. ${ }^{4}$ First, if learning and initial conditions are important, then the focus should be on new establishments rather than on incumbents. However, research data sets differ importantly on how they treat new and/or small firms. Some only

\footnotetext{
${ }^{4}$ Davis and Haltiwanger (1992) examined job reallocation behavior and the passive learning story within the manufacturing sector. While learning about initial conditions provided a plausible explanation for the sharp and pervasive relationship between job reallocation rates and plant age, on the more fundamental matter of explaining the overall magnitude of job reallocation, the passive learning story is far less successful. Learning about initial conditions accounts for a small portion, 11-13 percent, of total job reallocation.
}

sample small units and others cut them off at some arbitrary point. Second, labor economists have focused much of their work on gross employment effects and not on size issues per se (Moen 2005; Pakes and Nitzan 1983). Finally, because of data limitations, labor economists and industrial organization economists alike have typically focused on the manufacturing sector of the economy, to the exclusion of the much larger and more dynamic service sector (Davis et al. 1996b; Audretsch 1995; Klepper 2002). ${ }^{5}$

Recently as new and larger datasets have become available we are starting to see a much richer examination of the economy (Acs and Armington 2006, Acs and Storey 2004, Haltiwanger 2006). ${ }^{6}$ Armington and Acs (2004) looked at several aspects of employment dynamics in two industry sectors of very different capital intensity, to evaluate the competing theories of sunk capital versus learning and 'noisy' selection for explaining the determinants of change and the evolution of industry. In this literature noisy selection and entry are supposed to play a more important role than the fixity of capital in explaining the size distribution of firms and firm growth. They find substantial support for the theories of 'noisy' selection, and active and passive learning, in contrast to the traditional role asserted for sunk capital as determinant of employment dynamics and business survival.

\section{Data and measurement issues}

The Metropolitan Statistical Areas (MSAs) are used to test the relationship between start-up activity and employment effects. These areas consist of at least one urbanized area of 50,000 or more inhabitants and its adjacent zone of influence, e.g. neighboring cities or towns and adjoining areas. According to the MSA definition developed in the year 2000, there are currently 370 metropolitan areas in the United States. Although the Metro Areas do not cover the entire country, about 80 percent of all new businesses founded occur within metro areas (Lee et al. 2004). However, due to a change of definition of the MSAs

\footnotetext{
${ }_{5}^{5}$ For a recent exception see Klomp and Thurik (1999).

${ }^{6}$ For an overview see also Haviland and Savych (2005).
} 
in 2000 and the availability of other relevant data, complete data for all variables are only available for 320 MSAs.

The data on business dynamics are derived from the Longitudinal Establishment and Enterprise Microdata (LEEM) and was provided by the U.S. Small Business Administration (for a detailed explanation of the LEEM data, see Acs and Armington, 2006, Appendix A). ${ }^{7}$ The LEEM allows analyzing multiple years of annual data for every US private sector (nonfarm) business with employees. The current LEEM file facilitates tracking employment, payroll, and firm affiliation and (employment) size for establishments that existed at some time during 1989 through 2002. A business establishment (location or plant) is the basic unit of the LEEM data. An establishment is a single physical location where business is conducted or where services or industrial operations are performed. Each establishment for each year of its existence in terms of its employment, annual payroll, location (state, county and metropolitan area), primary industry, and start year is described by the LEEM. Additional data for each establishment and year identify the firm (or enterprise) to which the establishment belongs, and the total employment of that firm. These firms (may also be called enterprise or company) are the largest aggregation of business legal entities under common ownership or control. In most cases establishment and firm data are identical since the majority of firms are composed of only a single legal entity, which operates a single establishment. About four percent of firms have more than one establishment and therefore a small number of startups are set up as a new location of an existing firm.

Data on regional employment were provided by the US Bureau of Labor Statistics and is taken from the Current Employment Statistics (CES) Survey. The Current Employment Statistics (CES) Survey is a monthly survey of business establishments, which provides estimates of employment, hours, and earnings data by industry for the nation as a whole, all states, and most major metropolitan areas. Persons on establishment payrolls who receive pay for any part of the pay period, which includes the 12th of the month, are counted as employees. Persons are counted at their place of work rather than at their

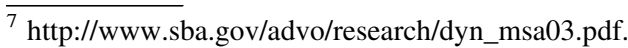

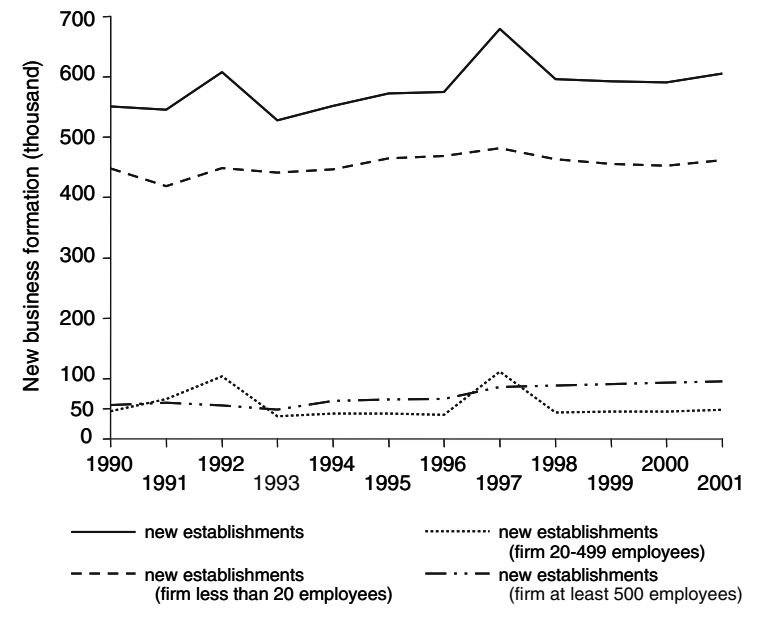

Fig. 1 New business formation over time in MSAs

place of residence; those appearing on more than one payroll are counted on each payroll.

The number of newly founded establishments has steadily increased since $1990 .{ }^{8}$ As shown in Fig. 1 there were about 550,000 new establishments in 1990 and 605,000 in 2001 . The majority of new establishments belong to a firm with less than 20 employees (about 78 percent). Most of these establishments are identical to a firm and are not a new location or plant. On average ten percent of the new establishments either started with 20 to 499 employees or belong to an existing parent company this size. ${ }^{9}$ It can be noticed clearly that the number of new establishments

\footnotetext{
${ }^{8}$ The two peaks corresponding to the years 1992 and 1997 represent economic census' years. The Bureau of the Census does a good job picking up new firms and the establishments of large plants through the company organization survey. However, it does not do a very good job of catching establishments of firms with less than 150 employees in non-census years.

9 The surge in new secondary establishments in 92 and 97 , results from the Economic Census when a big effort is made to identify all the secondary establishments accurately. Since the employment is fully reported each year, but is increasingly inaccurately imputed to the older known establishments (both primary for single-unit firms and secondary for multi-unit firms) the actual reporting on the accumulation of newly discovered secondary locations results in a corresponding fall in employment from the larger primary and secondary establishments to which the employment changes had previously been imputed. One could try to control for these special effects with a dummy for Census years that picks up the positive effects on numbers of new secondary establishments and the negative effects on employment reported as shifted from other establishments in those firms.
} 
belonging to a firm with at least 500 employees increased steadily. Its share increased from 10 to 16 percent since 1990. Most of these establishments are new locations and plants of existing firms and it can be assumed that these establishments have different preconditions than independent start-ups. These entrants may be larger in their first year of activity and experience better initial conditions.

In order to examine regional differences in new business formation activity, it is useful to control for differences in the size of regions and to account for the economic potential of each region. Therefore, start-up rates are estimated according to the labor market approach defined as new establishments per 1,000 employees (Acs and Armington 2004). Table 1 gives an overview of the start-up rate in the 50 Metropolitan Statistical Areas with the highest startup rate. Regions in Florida evidence high start-up rates, six of the top ten MSAs are located in Florida. Interestingly, the top ten MSAs regarding the start-up rate of all firms and small firms (less than 20 employees) are nearly identical. However, not all MSAs with a high start-up rate based on small establishments also exhibit a high start-up rate based on large firms (greater than 500 employees) or establishments belonging to a large parent company. If establishments that belong to a firm with at least 500 employees sort the start-up rate, 10 out of the top 20 are not even listed in the top 50 of the overall start-up rate (all establishments), e.g. FayettevilleSpringdale-Rogers (AR), Jacksonville (FL), Stamford-Norwalk (CT), Tallahassee (FL) and Denver (CO).

Start-up rates are strongly correlated over time and a large part of the variation of regional start-up rates can be explained by previous start-up activity (Table 2) ${ }^{10}$ However, the multiple regressions show that the high correlations decrease over time (column IV, Table 2). The start-up rate in year $t$ is mostly determined by the start-up rate of the previous year and only to some degree by the start-up rate ten years ago. This high degree of multicollinearity is also found in Germany, Great Britain and the Netherlands (Fritsch and Mueller 2004, 2007; Mueller et al. 2007, van Stel and Suddle 2007). Although we find a strong correlation

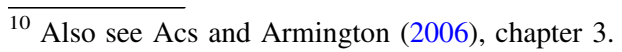

year by year, there are changes over time. The results indicate that regions do change over time. Across all regions, the start-up rate varies between 3 and 18 new establishments per 1,000 employees.

In order to analyze the long-term relationship between business dynamics and employment effects, we regress start-up rates in year $t$ and each of the preceding six years on employment change over a three-year period (percentage change between $t$ and $t+3$ ). Due to the strong correlation of start-up rates over time it can be expected that the regression model will suffer from a high degree of multicollinearity (Table 2). Therefore, the Almon lag method is used to avoid these problems of multicollinearity (for details see van Stel and Storey 2004; Greene 2003). This method imposes restrictions on the parameters of start-up rates there with the estimated coefficients of the start-up rates are a function of the lag length. We include the variable population density to control for other regional factors such as people movement, house prices and wages. The empirical analysis accounts for a panel of the years 1990 until 2003. The fixed effect estimator is used in the regressions in order to control for unobserved regional specific effects.

Since we regress regional employment on regional start-ups, a problem of omitted variables may arise. Different regions may be affected by different time variant effects, which are not captured by the fixed effects. For instance different sectoral structure of the different regions, the economic cycle and idiosyncratic shocks may affect local employment. A second issue has to do with possible endogeneity of the start-up regressors. If the boom of the 1990 increased both the employment and the start-up rate both the dependent and the independent variable are co-determined by the local favorable economic conditions. This could be controlled by the inclusion of regional control variables. The role of industry-mix but also broader regional heterogeneity could be addressed. These issues are partly addressed by the different types of entry across regions.

\section{Empirical results}

This paper examines the effect of business dynamics on employment changes at the regional level. The 
Table 1 New business formation rates, average 1998-2001, for selected Metropolitan Statistical Areas, sorted by overall start-up rate

\begin{tabular}{|c|c|c|c|c|c|}
\hline \multirow[t]{2}{*}{ MSA } & \multirow[t]{2}{*}{ MSA Name } & \multicolumn{4}{|c|}{ Average start-up rate 1998-2001 (establishments per 1,000 employees) } \\
\hline & & All firms & $\begin{array}{l}\text { Firm <20 } \\
\text { employees }\end{array}$ & $\begin{array}{l}\text { Firm 20-499 } \\
\text { employees }\end{array}$ & $\begin{array}{l}\text { Firm } \geq 500 \\
\text { employees }\end{array}$ \\
\hline 1150 & Bremerton, WA & 13.42 & 11.25 & 0.92 & 1.25 \\
\hline 5345 & Naples, FL & 12.02 & 10.14 & 0.69 & 1.19 \\
\hline 7490 & Santa Fe, NM & 11.85 & 9.88 & 0.58 & 1.39 \\
\hline 6580 & Punta Gorda, FL & 11.43 & 9.53 & 0.48 & 1.42 \\
\hline 5910 & Olympia, WA & 11.33 & 9.72 & 0.58 & 1.04 \\
\hline 2710 & Fort Pierce-Port St. Lucie, FL & 11.25 & 9.25 & 0.64 & 1.36 \\
\hline 2700 & Fort Myers-Cape Coral, FL & 11.24 & 8.76 & 0.77 & 1.72 \\
\hline 2680 & Fort Lauderdale, FL & 11.00 & 9.19 & 0.65 & 1.16 \\
\hline 2995 & Grand Junction, CO & 10.71 & 8.92 & 0.66 & 1.14 \\
\hline 8960 & West Palm Beach-Boca Raton, FL & 10.51 & 8.65 & 0.65 & 1.21 \\
\hline 4100 & Las Cruces, NM & 10.31 & 7.97 & 0.84 & 1.50 \\
\hline 860 & Bellingham, WA & 10.30 & 8.82 & 0.62 & 0.85 \\
\hline 7460 & San Luis Obispo-Atasc.-Paso Robles, CA & 10.25 & 8.53 & 0.69 & 1.03 \\
\hline 2620 & Flagstaff, UT-AZ & 10.25 & 8.26 & 0.74 & 1.26 \\
\hline 3605 & Jacksonville, NC & 10.12 & 7.69 & 0.95 & 1.49 \\
\hline 2020 & Daytona Beach, FL & 10.10 & 8.30 & 0.60 & 1.20 \\
\hline 740 & Barnstable-Yarmouth, MA & 10.08 & 8.68 & 0.62 & 0.78 \\
\hline 9200 & Wilmington, NC & 10.06 & 8.34 & 0.61 & 1.10 \\
\hline 5330 & Myrtle Beach, SC & 9.99 & 7.88 & 0.82 & 1.30 \\
\hline 4890 & Medford-Ashland, OR & 9.80 & 8.23 & 0.65 & 0.92 \\
\hline 5000 & Miami, FL & 9.78 & 8.37 & 0.55 & 0.85 \\
\hline 5190 & Monmouth-Ocean, NJ & 9.70 & 8.26 & 0.50 & 0.93 \\
\hline 2670 & Fort Collins-Loveland, CO & 9.68 & 7.98 & 0.62 & 1.08 \\
\hline 1580 & Cheyenne, WY & 9.57 & 7.60 & 0.54 & 1.43 \\
\hline 4080 & Laredo, TX & 9.36 & 7.69 & 0.68 & 0.99 \\
\hline 1350 & Casper, WY & 9.31 & 7.09 & 0.68 & 1.54 \\
\hline 5140 & Missoula, MT & 9.28 & 7.78 & 0.53 & 0.97 \\
\hline 8200 & Tacoma, WA & 9.25 & 7.65 & 0.56 & 1.03 \\
\hline 5790 & Ocala, FL & 9.24 & 7.61 & 0.54 & 1.09 \\
\hline 7500 & Santa Rosa, CA & 9.23 & 7.82 & 0.57 & 0.84 \\
\hline 2750 & Fort Walton Beach, FL & 9.18 & 6.98 & 0.73 & 1.47 \\
\hline 1125 & Boulder-Longmont, CO & 9.16 & 7.37 & 0.58 & 1.22 \\
\hline 4880 & McAllen-Edinburg-Mission, TX & 9.03 & 7.25 & 0.78 & 1.00 \\
\hline 7080 & Salem, OR & 9.01 & 7.20 & 0.79 & 1.02 \\
\hline 5380 & Nassau-Suffolk, NY & 8.93 & 7.69 & 0.41 & 0.83 \\
\hline 6690 & Redding, CA & 8.90 & 7.33 & 0.63 & 0.93 \\
\hline 7120 & Salinas, CA & 8.86 & 7.30 & 0.66 & 0.90 \\
\hline 3285 & Hattiesburg, MS & 8.85 & 6.59 & 0.84 & 1.42 \\
\hline 1080 & Boise City, ID & 8.62 & 6.60 & 0.56 & 1.45 \\
\hline 7480 & Santa Barbara-Santa Maria-Lompoc, CA & 8.60 & 6.97 & 0.70 & 0.93 \\
\hline 6015 & Panama City, FL & 8.59 & 6.52 & 0.79 & 1.29 \\
\hline
\end{tabular}


Table 1 continued

\begin{tabular}{llllll}
\hline MSA & MSA Name & \multicolumn{2}{l}{ Average start-up rate 1998-2001 } & (establishments per 1,000 employees) \\
\cline { 3 - 5 } & All firms & $\begin{array}{l}\text { Firm <20 } \\
\text { employees }\end{array}$ & $\begin{array}{l}\text { Firm 20-499 } \\
\text { employees }\end{array}$ & $\begin{array}{l}\text { Firm } \geq 500 \\
\text { employees }\end{array}$ \\
\hline 7510 & Sarasota-Bradenton, FL & 8.59 & 7.05 & 0.48 & 1.06 \\
880 & Billings, MT & 8.54 & 6.67 & 0.61 & 1.27 \\
3040 & Great Falls, MT & 8.47 & 6.65 & 0.58 & 1.24 \\
3060 & Greeley, CO & 8.35 & 7.12 & 0.45 & 0.79 \\
8735 & Ventura, CA & 8.35 & 6.58 & 0.63 & 1.14 \\
2400 & Eugene-Springfield, OR & 8.28 & 6.88 & 0.62 & 0.78 \\
7485 & Santa Cruz-Watsonville, CA & 8.28 & 7.17 & 0.50 & 0.61 \\
7320 & San Diego, CA & 8.25 & 6.55 & 0.67 & 1.03 \\
5660 & Newburgh, NY-PA & 8.21 & 6.72 & 0.51 & 0.98 \\
\hline
\end{tabular}

Source: Start-ups from 1989-2001 LEEM file, US Bureau of the Census. Employment from CES Survey

econometric analysis accounts for time lags that might be involved for the employment effects to evolve. New establishments have a strong positive employment effect the year they enter the market (Table 3). The empirical results show that the effects are decreasing over time. From the unrestricted regression we also find a negative employment effect of business dynamics, which might also be due to the high degree of multicollinearity. The results of the Almon polynomial lags indicate that the employment effect is decreasing over time but is never negative. Interestingly, those new establishments set up four or five years ago have a higher impact on employment growth than new establishments that entered two or three years ago. The results suggest that the employment effects of business dynamics fade away after six years.

The employment effects over time are illustrated by Fig. 2. It can be clearly seen that the overall employment effect is positive leading to the conclusion that business dynamics lead to employment growth but the employment effects last only for about six years. Furthermore, our results support the outcomes of Fritsch and Mueller $(2004,2007)$ as well as Mueller et al. (2007). Both studies found new businesses to have a strong positive employment effect shortly after entering the market the effects decrease over time and reach a second maximum after about 5 years before the employment effects fade away.
In order to gain further insight into the relationship of business dynamics and employment effects, we differentiate new establishments according to the size of the parent company. First, we analyze the employment effects of new firms with less than 20 employees; in this case the new establishment is mostly identical to a new firm. Second, we focus on the employment effects of new establishments that count either between 20 and 499 employees or belong to a parent company with 20 to 499 employees. Finally we address new establishments of firms with more than 500 employees. This distinction is expected to shed light on the question which new establishments cause the shape of the distribution of employment effects. We expect the long-term effects to be more pronounced for larger entrants or new locations and plants of multi-unit companies. New plants or locations of existing firms are most likely supported by their parent company, which results in better initial conditions. Furthermore, larger entrants have better survival chances and are more likely to create employment over time (Bruderl et al. 1992). Thus, these new establishments are more likely to stimulate the performance of incumbent businesses, which consequently leads to employment growth in the region.

The distinction of the three groups of new establishments indicates that the magnitude of the employment effects and the distribution of the effects over time mainly depend on the size of the 
Table 2 Correlation of start-up rates over time

\begin{tabular}{lllll}
\hline & \multicolumn{2}{l}{ Start-up rate $(t)$} & & \\
\cline { 2 - 5 } & $(\mathrm{I})$ & $(\mathrm{II})$ & $(\mathrm{III})$ & $(\mathrm{IV})$ \\
\hline Start-up rate $(t-1)$ & $0.8871^{* *}(114.48)$ & - & - & $0.6125 * *(16.79)$ \\
Start-up rate $(t-5)$ & - & $0.9148^{* *}(106.86)$ & - & $0.2805 * *(6.92)$ \\
Start-up rate $(t-10)$ & - & - & $0.8502 * *(39.82)$ & $0.0824 * *(3.20)$ \\
$R^{2}$-adjusted & 0.7869 & 0.8369 & 0.7223 & 0.9195 \\
$F$-Value & 13106.36 & 11420.10 & 1585.27 & 2065.06 \\
Observations & 3549 & 2226 & 610 & 610 \\
\hline
\end{tabular}

Pooled regression, beta-coefficients, $t$-values in parentheses

** Significant at the $1 \%$ level

firm. Market entry of small new establishments is limited to short-term employment effects. In this case, the employment effects decrease over time and are negligible after five years (Table 4, column I and II). We do not detect a long-term employment effect for this group of new establishments. The distribution of the employment effects is illustrated in Fig. 3.

New establishments of firms with 20 to 499 employees or new firms of this size are mainly responsible for the lagged employment effect of business dynamics (Table 4 columns III and IV). The results clearly indicate that this group of new establishments unfolds its employment effect after a time lag of two years. New establishments set up five years ago have the strongest employment effect. An explanation for their strong long-term employment effect may be that these establishments are more likely to increase their level of productivity soon after entry due to their entry size and initial conditions. The employment effects may be attributed to the creation of employment in these start-up cohorts as well as employment in incumbents who are challenged by their entry. The distribution of the employment effects for this group of entrants is illustrated in Fig. 4.

In 2002-2003 there were 612,296 new firms and 121,929 new secondary establishments in the economy as a whole. ${ }^{11}$ A more careful examination of this suggests that the 20-499 size parent firm has only about 4 percent of the new firms and 20 percent of the

\footnotetext{
11 http://www.sba.gov/advo/research/dyn_us03.pdf. Accessed on January 11, 2007.
}

new secondary establishments. ${ }^{12}$ There were 26,424 new firms and 24,143 new secondary locations for a total of 50,567 new establishments. The distribution of these establishments across the two firm size classes is quite different. First, for new firms 23,901 belonged to the 20-99 firm size class and 2,532 to the 100-499 firm size class. So entry is predominantly in the smaller firm size class. For secondary establishments 7,726 belong to the 20-99 firm size class and 16,417 belong to the $100-499$ firm size class. In other words, these Gazelles grow because they enter or grow very quickly to an initial size that is greater than 20 employees and then add secondary establishments once they reach more than 100 employees. It is this employment dynamic that seems to explain the employment effects over time. What is unique about the Gazelles is that they add both primary and secondary locations. While mice $(<20)$ add almost no secondary locations and elephants $(>500)$ add only establishments and almost no new firms.

Most of the new firms are located in a few industries. Primary locations are to be found in Accommodations and Food Services $(6,890)$, Health Care and Social Assistance $(2,209)$, Retail trade $(2,137)$ and Construction $(2,031)$. The secondary locations are to be found in Retail Trade $(3,130)$, Health Care and Social Assistance $(2,688)$, Finance and Insurance $(2,052)$ and Accommodations and Food Services $(2,688)$.

The distinction between the new establishments according to the size of the firm reveals that a negative

\footnotetext{
${ }^{12}$ The 4 percent figure is consistent with many other studies on Gazelles.
} 
Table 3 Impact of new business formation on employment change

Employment change 3 years (\%) (establishments of all firms)

(I) Unrestricted regression

(II) Regression with Almon polynomial lags

\begin{tabular}{|c|c|c|c|c|}
\hline Start-up rate $(t)$ & $2.324 * *(13.06)$ & $\alpha_{1}$ & $2.446 * *(18.40)$ & 2.446 \\
\hline Start-up rate $(t-1)$ & $1.295^{* *}(6.89)$ & $\alpha_{2}$ & $-1.833 * *(8.59)$ & 1.144 \\
\hline Start-up rate $(t-2)$ & $-0.247(1.24)$ & $\alpha_{3}$ & $0.587 * *(7.19)$ & 0.676 \\
\hline Start-up rate $(t-3)$ & $-0.696 * *(2.89)$ & $\alpha_{4}$ & $-0.057 * *(6.70)$ & 0.701 \\
\hline Start-up rate $(t-4)$ & $1.678 * *(11.19)$ & & & 0.878 \\
\hline Start-up rate $(t-5)$ & $0.355^{*}(2.37)$ & & & 0.867 \\
\hline Start-up rate $(t-\sigma)$ & $0.000(0.000)$ & & & 0.328 \\
\hline Population density & $-0.150 * *(3.72)$ & & & $-0.187 * *(3.95)$ \\
\hline Constant & $-3.230(0.36)$ & & & $-13.620(1.27)$ \\
\hline$R^{2}$-adjusted & 0.4831 & & & 0.4260 \\
\hline$F$-Value & 109.47 & & & 147.79 \\
\hline Log-likelihood Value & -3978.67 & & & -4062.40 \\
\hline Observations & 1569 & & & 1569 \\
\hline
\end{tabular}

Notes: Significant at $* 5 \%, * * 1 \%$; absolute value of the $t$-statistics in parentheses

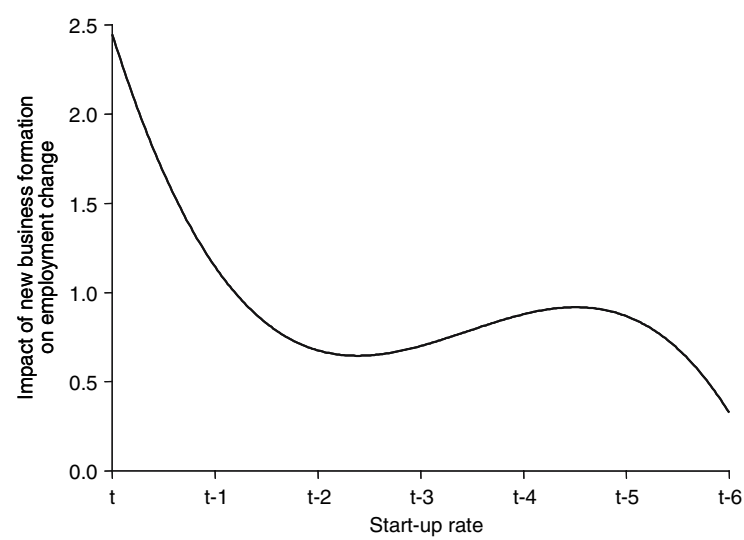

Fig. 2 Employment effects over time-all new establishments

employment effect may also exist. The entry of new establishments of parent companies with at least 500 employees has strong negative employment effects. However, the employment effect turns positive six years after entry. One explanation for this phenomenon may be that most of these entrants are new locations of large multi-unit corporations and that these establishments may enter the market with a high productivity level (Foster et al. 2006). Thus, their entry forces existing businesses to exit the market, which leads to employment losses in the region. Nevertheless, it can be expected that their entry is important since they force inefficient business to leave the market, which leads to a positive employment effect in the long run. The employment effects over time of this group of entrants are illustrated in Fig. 5.

\section{Gazelle regions}

Gazelle regions are regions that have a predominance of rapidly growing companies (at least one percent of all Gazelles are located in these MSAs). Table 5 gives an overview of new establishments of firms with 20 499 employees and the average concentration of these new establishments. About $4.2 \%$ of all Gazelles in the United States are located in Los Angeles, followed by Chicago and New York City each with $3.2 \%$ and Washington D.C. with 2.4\%. Interestingly, 40 percent of all the Gazelles are located in only 20 MSAs, which are mostly the largest cities in the United States.

The Gazelle regions are concentrated at the west coast and east coast as well as around Chicago. Most of the gazelle regions are home to major universities and research facilities. Furthermore, these regions are characterized by a high share of employment in the creative class and service class (Florida 2002, p. 237). They are also large cities. This may in part explain why they support Gazelles. The large city size allows for the entry of secondary locations around or near 
Table 4 Impact of new business formation on employment change, by size of firm

\begin{tabular}{|c|c|c|c|c|c|c|c|c|c|c|c|c|}
\hline & \multicolumn{12}{|c|}{ Employment change 3 years $(\%)$} \\
\hline & \multicolumn{4}{|c|}{$\begin{array}{l}\text { Establishments, firms <20 } \\
\text { employees }\end{array}$} & \multicolumn{4}{|c|}{$\begin{array}{l}\text { Establishments, firms 20-499 } \\
\text { employees }\end{array}$} & \multicolumn{4}{|c|}{$\begin{array}{l}\text { Establishments, firms } \geq 500 \\
\text { employees }\end{array}$} \\
\hline & $\begin{array}{l}\text { (I) } \\
\text { Un- } \\
\text { restricted }\end{array}$ & & $\begin{array}{l}\text { Regressio } \\
\text { mon polyn } \\
\text { S }\end{array}$ & $\begin{array}{l}\text { n with } \\
\text { omial }\end{array}$ & $\begin{array}{l}\text { (III) } \\
\text { Un- } \\
\text { restricted }\end{array}$ & $\begin{array}{l}\text { (IV } \\
\text { Alr } \\
\text { lag }\end{array}$ & $\begin{array}{l}\text { J) Regressi } \\
\text { mon polyn } \\
\text { S }\end{array}$ & $\begin{array}{l}\text { on with } \\
\text { omial }\end{array}$ & $\begin{array}{l}(\mathrm{V}) \\
\text { Un- } \\
\text { restricted }\end{array}$ & $\begin{array}{l}\text { (VI } \\
\text { Alr } \\
\text { lag }\end{array}$ & $\begin{array}{l}\text { I) Regressic } \\
\text { mon polyno } \\
\text { S }\end{array}$ & $\begin{array}{l}\text { on with } \\
\text { omial }\end{array}$ \\
\hline $\begin{array}{l}\text { Start-up rate } \\
\quad(t)\end{array}$ & $\begin{array}{l}3.198 * * \\
(11.33)\end{array}$ & $\alpha_{1}$ & $\begin{array}{l}3.250 * * \\
(14.95)\end{array}$ & 3.250 & $\begin{array}{l}1.925^{* *} \\
(2.87)\end{array}$ & $\alpha_{1}$ & $\begin{array}{l}1.182 * * \\
(2.66)\end{array}$ & 1.182 & $\begin{array}{l}-2.489 * * \\
(4.03)\end{array}$ & $\alpha_{1}$ & $\begin{array}{l}-2.234 * * \\
(4.66)\end{array}$ & -2.234 \\
\hline $\begin{array}{l}\text { Start-up rate } \\
\quad(t-1)\end{array}$ & $\begin{array}{l}2.400 * * \\
(7.44)\end{array}$ & $\alpha_{2}$ & $\begin{array}{l}-1.121 * * \\
(2.85)\end{array}$ & 2.238 & $\begin{array}{l}0.677 \\
(0.95)\end{array}$ & $\alpha_{2}$ & $\begin{array}{l}-1.016^{*} \\
(2.14)\end{array}$ & 0.904 & $\begin{array}{l}-4.320 * * \\
(7.52)\end{array}$ & $\alpha_{2}$ & $\begin{array}{l}-3.286^{* * *} \\
(4.22)\end{array}$ & -4.918 \\
\hline $\begin{array}{l}\text { Start-up rate } \\
\quad(t-2)\end{array}$ & $\begin{array}{l}1.244 * * \\
(4.27)\end{array}$ & $\alpha_{3}$ & $\begin{array}{l}0.112 \\
(0.75)\end{array}$ & 1.442 & $\begin{array}{l}-0.366 \\
(0.54)\end{array}$ & $\alpha_{3}$ & $\begin{array}{l}0.836^{* *} \\
(5.25)\end{array}$ & 1.706 & $\begin{array}{l}-6.644 * * \\
(8.62)\end{array}$ & $\alpha_{3}$ & $\begin{array}{l}0.603 \\
(1.77)\end{array}$ & -6.404 \\
\hline $\begin{array}{l}\text { Start-up rate } \\
(t-3)\end{array}$ & $\begin{array}{l}0.798 * \\
(2.27)\end{array}$ & $\alpha_{4}$ & $\begin{array}{l}-0.002 \\
(0.10)\end{array}$ & 0.851 & $\begin{array}{l}-1.810^{* *} \\
(2.57)\end{array}$ & $\alpha_{4}$ & $\begin{array}{l}-0.099 * * \\
(6.87)\end{array}$ & 2.997 & $\begin{array}{l}-7.107 * * \\
(10.77)\end{array}$ & $\alpha_{4}$ & $\begin{array}{l}-0.001 \\
(0.03)\end{array}$ & -6.701 \\
\hline $\begin{array}{l}\text { Start-up rate } \\
(t-4)\end{array}$ & $\begin{array}{l}0.600 * \\
(2.08)\end{array}$ & & & 0.456 & $\begin{array}{l}4.040 * * \\
(7.41)\end{array}$ & & & 4.184 & $\begin{array}{l}-5.811 * * \\
(8.43)\end{array}$ & & & -5.814 \\
\hline $\begin{array}{l}\text { Start-up rate } \\
(t-5)\end{array}$ & $\begin{array}{l}0.175 \\
(0.85)\end{array}$ & & & 0.249 & $\begin{array}{l}2.390^{* *} \\
(4.67)\end{array}$ & & & 4.676 & $\begin{array}{l}-3.129 * * \\
(4.08)\end{array}$ & & & -3.752 \\
\hline $\begin{array}{l}\text { Start-up rate } \\
\quad(t-6)\end{array}$ & $\begin{array}{l}0.227 \\
(1.18)\end{array}$ & & & 0.220 & $\begin{array}{l}1.624 * * \\
(3.27)\end{array}$ & & & 3.881 & $\begin{array}{l}-0.760 \\
(0.86)\end{array}$ & & & -0.522 \\
\hline $\begin{array}{l}\text { Population } \\
\text { density }\end{array}$ & $\begin{array}{l}-0.150^{* *} \\
(3.84)\end{array}$ & & & $\begin{array}{l}-0.152 * * \\
(3.88)\end{array}$ & $\begin{array}{l}-0.125^{* *} \\
(3.51)\end{array}$ & & & $\begin{array}{l}-0.162^{* *} \\
(9.98)\end{array}$ & $\begin{array}{l}-0.143^{* *} \\
(2.94)\end{array}$ & & & $\begin{array}{l}-0.143 * * \\
(8.60)\end{array}$ \\
\hline Constant & $\begin{array}{l}-17.360 * \\
(2.05)\end{array}$ & & & $\begin{array}{l}-17.486^{*} \\
(2.07)\end{array}$ & $\begin{array}{l}19.035^{* *} \\
(2.84)\end{array}$ & & & $\begin{array}{l}17.220^{* *} \\
(4.74)\end{array}$ & $\begin{array}{l}53.127 * * \\
(6.69)\end{array}$ & & & $\begin{array}{l}53.175^{* *} \\
(19.11)\end{array}$ \\
\hline$R^{2}$-adjusted & 0.4755 & & & 0.4763 & 0.5311 & & & 0.3093 & 0.4435 & & & 0.2960 \\
\hline$F$-Value & 82.46 & & & 164.89 & 123.91 & & & 205.46 & 67.37 & & & 199.14 \\
\hline $\begin{array}{l}\text { Log- } \\
\text { likelihood } \\
\text { Value }\end{array}$ & -3990.12 & & & -3990.96 & -3902.31 & & & -4027.84 & -4036.61 & & & -4038.83 \\
\hline Observations & 1569 & & & 1569 & 1569 & & & 1569 & 1569 & & & 1569 \\
\hline
\end{tabular}

Notes: Significant at *5\%,**1\%; absolute value of the $t$-statistics is in parentheses

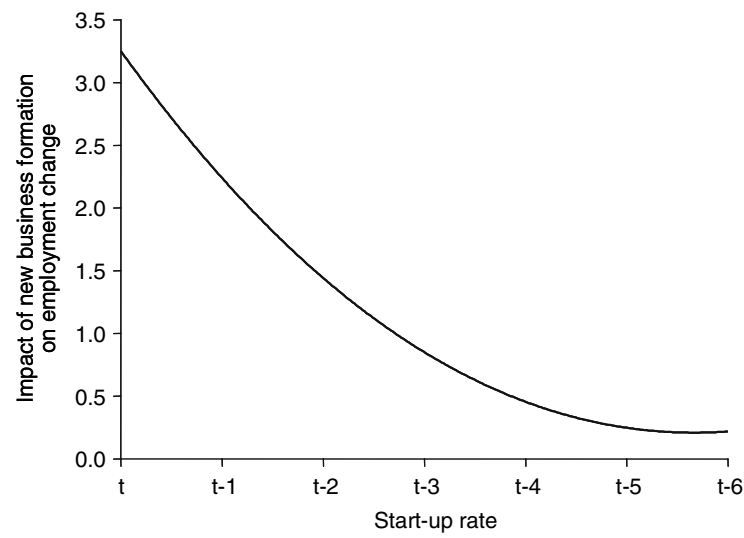

Fig. 3 Employment effects over time-new establishments of firms $<20$ employees

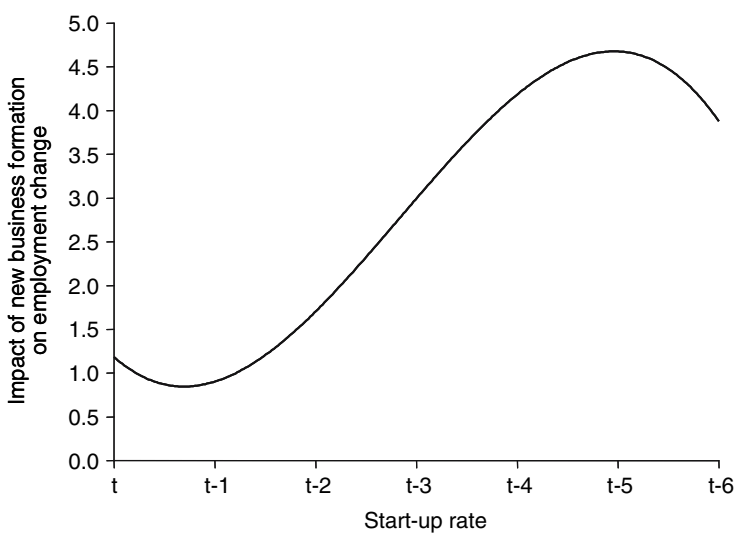

Fig. 4 Employment effects over time-start-ups of firms 20499 employees 
the parent firm. The four large consolidated metropolitan areas are futile ground for the growth of new businesses. Whereas small towns and cities can easily support new firm entry or new plant entry they cannot support the expansion of rapidly growing firms (Map 1).

The empirical analysis includes an interaction dummy in order to differentiate between regions that have a predominance of Gazelles and regions with low presence of Gazelles. The results indicate that the basic pattern of the employment effects is similar for both types of regions. However, Gazelle regions experience a stronger direct employment effect of start-ups than regions with a lower concentration of Gazelles (Table 6, column I and II). The initial employment effects at the time new firms start their activity is almost twice as much. Similar to our results presented in Table 3, where we did not differentiate between establishments or regions, the employment effects fade away after about five years whether a new establishment is set up in a Gazelle region or not.

Further analysis shows that the location of a fast growing establishment is critical. In comparison to new firms that mostly stay small (Mice) and the branches of large firms that are not integrated into local economies (Elephants), in which case it does not matter where they are set up, high potential firms (Gazelles) develop strong long-term employment effects after entry. For Gazelles, we find positive short-term employment effects, negative employment effects two years after entrance and pronounced long-term employment effects. Gazelles unfold their major employment effects after they have been in business for at least five years (Table 6, column III and IV). The results suggest that the average employment effects for Gazelles that are not in Gazelle regions are the same as for small firms (see Fig. 6 for illustration of the results). This raises questions about what type of regions is fertile ground for rapidly growing firms. Gazelle regions are predominantly larger cities in the United States, which exhibit a highly competitive environment. New firms have to grow rapidly in order to increase their likelihood of survival. Furthermore, incumbent firms might be more likely to absorb the challenge due to the entrance of new

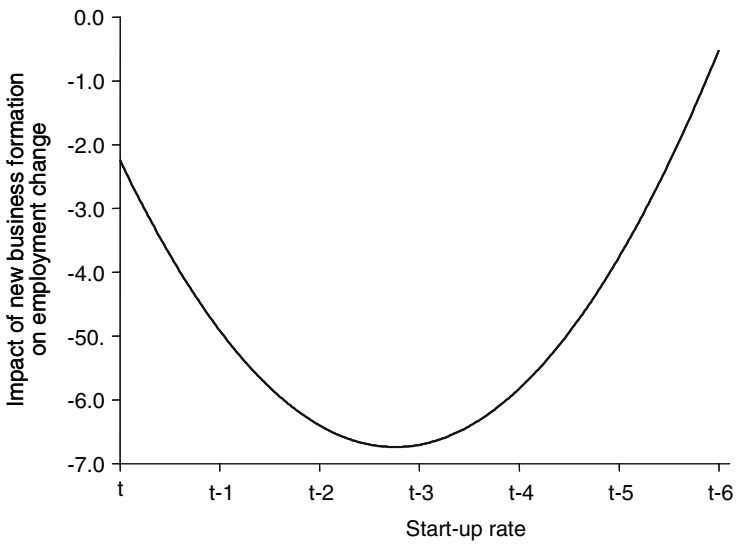

Fig. 5 Employment effects over time-start-ups with firm $\geq 500$ employees

establishments and react by increasing their efficiency. If learning and initial conditions are important for the employment effects of new businesses, rapidly growing firms in Gazelle regions might benefit from the business environment in these regions. These results are consistent with recent results on firm survival where survival is incumbent on sectoral diversity (Acs et al. 2007). This favorable business environment might also be characterized by high levels of creative capitaltalent, technology and tolerance (Florida 2002).

\section{Conclusion}

Much of the theoretical work on industry dynamics focuses on the role of 'noisy' selection and incomplete information on entry and survival. This paper extends research on industry dynamics by looking at the impact of firm heterogeneity on employment persistence. We find that firm heterogeneity has an important impact on employment effects over time. Moreover, we also find that it depends on the regional characteristics of the location of start-up. Some regions are more receptive to certain types of startups than others. Therefore, both the type of entry and the characteristics of the region are important for employment growth.

In comparison to other results, i.e. Germany, Great Britain or the Netherlands, the results for the United 
Table 5 Classified Gazelle Regions

\begin{tabular}{|c|c|c|c|}
\hline MSA Code & MSA & $\begin{array}{l}\text { Average start-up rate } \\
\text { (firms 20-499 employees) }\end{array}$ & $\begin{array}{l}\text { Average concentration } \\
\text { of new establishments } \\
\text { (firms } 20-499 \text { employees) }\end{array}$ \\
\hline 4480 & Los Angeles-Long Beach, CA & 0.69 & $4.25 \%$ \\
\hline 1600 & Chicago, IL & 0.52 & $3.18 \%$ \\
\hline 5600 & New York, NY & 0.51 & $3.18 \%$ \\
\hline 8840 & Washington, DC-MD-VA-WV & 0.72 & $2.35 \%$ \\
\hline 520 & Atlanta, GA & 0.80 & $2.27 \%$ \\
\hline 1920 & Dallas, TX & 0.82 & $2.14 \%$ \\
\hline 3360 & Houston, TX & 0.72 & $2.06 \%$ \\
\hline 6160 & Philadelphia, PA-NJ & 0.58 & $2.00 \%$ \\
\hline 2160 & Detroit, MI & 0.57 & $1.79 \%$ \\
\hline 1120 & Boston, MA-NH & 0.58 & $1.67 \%$ \\
\hline 6200 & Phoenix-Mesa, AZ & 0.82 & $1.62 \%$ \\
\hline 5120 & Minneapolis-St. Paul, MN-WI & 0.64 & $1.54 \%$ \\
\hline 7600 & Seattle-Bellevue-Everett, WA & 0.73 & $1.39 \%$ \\
\hline 7320 & San Diego, CA & 0.92 & $1.38 \%$ \\
\hline 2080 & Denver, CO & 0.78 & $1.21 \%$ \\
\hline 7040 & St. Louis, MO-IL & 0.60 & $1.16 \%$ \\
\hline 7360 & San Francisco, CA & 0.78 & $1.16 \%$ \\
\hline 6780 & Riverside-San Bernardino, CA & 1.00 & $1.15 \%$ \\
\hline 8280 & Tampa-St. Petersburg-Clearwater, FL & 0.74 & $1.13 \%$ \\
\hline 720 & Baltimore, MD & 0.65 & $1.07 \%$ \\
\hline 5775 & Oakland, CA & 0.79 & $1.06 \%$ \\
\hline 5000 & Miami, FL & 0.70 & $1.03 \%$ \\
\hline 6280 & Pittsburgh, PA & 0.61 & $1.01 \%$ \\
\hline
\end{tabular}

Start-up rate $=$ establishments per 1,000 employees

Map 1 Map of Gazelle regions

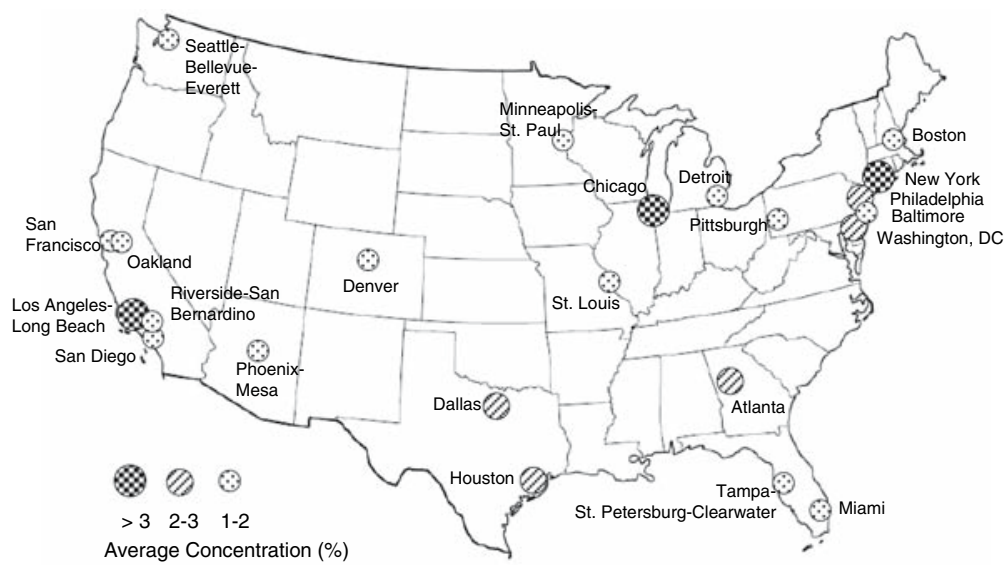


Table 6 Impact of new business formation on employment change: gazelle-regions

\begin{tabular}{|c|c|c|c|c|c|c|c|}
\hline & \multicolumn{7}{|c|}{ Employment change 3 years $(\%)$} \\
\hline & \multicolumn{4}{|c|}{ Establishments (all firms) } & \multicolumn{3}{|c|}{ Establishments (firms 20-499 employees) } \\
\hline & \multirow[t]{2}{*}{$\begin{array}{l}\text { (I) Unrestricted } \\
\text { regression }\end{array}$} & \multicolumn{3}{|c|}{$\begin{array}{l}\text { (II) Regression with } \\
\text { Almon polynomial lag }\end{array}$} & \multirow[t]{2}{*}{$\begin{array}{l}\text { (III) } \\
\text { Unrestricted }\end{array}$} & \multicolumn{2}{|c|}{$\begin{array}{l}\text { (IV) Regression with } \\
\text { Almon polynomial lag }\end{array}$} \\
\hline \multicolumn{6}{|l|}{ Gazelle regions } & & \\
\hline Start-up rate $(t)$ & $5.419 * *(5.39)$ & $\alpha_{1}$ & $4.578 * *(6.56)$ & 4.578 & $2.674(0.66)$ & $\alpha_{1} 2.520(1.50)$ & 2.520 \\
\hline Start-up rate $(t-1)$ & $2.041 *(2.30)$ & $\alpha_{2}$ & $\begin{array}{c}-2.797 * * \\
(3.46)\end{array}$ & 2.399 & $-3.256(0.72)$ & $\begin{array}{cc}\alpha_{2} & -4.231 * * \\
& (2.56)\end{array}$ & -0.454 \\
\hline Start-up rate $(t-2)$ & $-0.720(1.15)$ & $\alpha_{3}$ & $0.671 *(2.35)$ & 1.243 & $-8.427 *(2.27)$ & $\alpha_{3} 1.360 *(2.38)$ & -1.324 \\
\hline Start-up rate $(t-3)$ & $\begin{array}{l}-2.332 * * \\
(3.11)\end{array}$ & $\alpha_{4}$ & $-0.053(1.93)$ & 0.792 & $\begin{array}{l}-11.896 * * \\
(3.05)\end{array}$ & $\alpha_{4}-0.103^{*}(2.38)$ & -0.708 \\
\hline Start-up rate $(t-4)$ & $2.497 * *(5.78)$ & & & 0.723 & $2.367(0.91)$ & & 0.778 \\
\hline Start-up rate $(t-5)$ & $-0.760(0.89)$ & & & 0.719 & $-0.630(0.22)$ & & 2.518 \\
\hline Start-up rate $(t-\sigma)$ & $-0.047(0.07)$ & & & 0.458 & $0.896 * * 0.30)$ & & 3.894 \\
\hline \multicolumn{8}{|c|}{ Non-gazelle regions } \\
\hline Start-up rate $(t)$ & $\begin{array}{l}2.241 * * \\
(12.90)\end{array}$ & $\alpha_{1}$ & $\begin{array}{l}2.363 * * \\
(14.86)\end{array}$ & 2.363 & $1.815 * * 2.70)$ & $\begin{array}{rr}\alpha_{1} & 3.185 * * \\
& (11.83)\end{array}$ & 3.185 \\
\hline Start-up rate $(t-1)$ & $1.229 * *(6.48)$ & $\alpha_{2}$ & $\begin{array}{c}-1.823 * * \\
\quad(8.16)\end{array}$ & 1.077 & $0.5990 .84)$ & $\alpha_{2}-1.090 *(2.46)$ & 2.197 \\
\hline Start-up rate $(t-2)$ & $-0.283(1.38)$ & $\alpha_{3}$ & $0.596 *(7.13)$ & 0.634 & $-0.3410 .50)$ & $\alpha_{3} \quad 0.104(0.61)$ & 1.413 \\
\hline Start-up rate $(t-3)$ & $\begin{array}{l}-0.690 * * \\
(2.79)\end{array}$ & $\alpha_{4}$ & $-0.058(6.81)$ & 0.684 & $-1.704 * 2.40)$ & $\alpha_{4}-0.001(0.05)$ & 0.825 \\
\hline Start-up rate $(t-4)$ & $\begin{array}{l}1.681^{* *} \\
(11.18)\end{array}$ & & & 0.878 & $3.998 * * 7.25)$ & & 0.429 \\
\hline Start-up rate $(t-5)$ & $0.356(0.12)$ & & & 0.868 & $2.371 * *(4.62)$ & & 0.219 \\
\hline Start-up rate $(t-6)$ & $-0.019(0.12)$ & & & 0.302 & $1.602 * *(3.22)$ & & 0.190 \\
\hline $\begin{array}{l}\text { Population } \\
\text { density }\end{array}$ & $\begin{array}{l}-0.122 * * \\
\quad(3.46)\end{array}$ & & & $\begin{array}{l}-0.172 * * \\
\quad(3.79)\end{array}$ & $-0.099 * *(3.30)$ & & $-0.132 * *(3.76)$ \\
\hline Constant & $-7.515(0.95)$ & & & $-16.797(1.63)$ & $16.166 * *(2.84)$ & & $\begin{array}{l}-19.477 * * \\
(2.59)\end{array}$ \\
\hline$R^{2}$-adjusted & 0.4949 & & & 0.4328 & 0.5438 & & 0.4866 \\
\hline$F$-Value & $82.67 * *$ & & & $100.45^{* *}$ & $94.74 * *$ & & $109.38 * *$ \\
\hline $\begin{array}{l}\text { Log-likelihood } \\
\quad \text { Value }\end{array}$ & -3957.06 & & & -4051.05 & -3877.15 & & -3972.94 \\
\hline Observations & 1569 & & & 1569 & 1569 & & 1569 \\
\hline
\end{tabular}

Notes: Significant at *5\%,**1\%; absolute value of the $t$-statistics is in parentheses

States show that the effect of new small establishments on employment is mainly in the first years after set-up and the employment effect decreases over time. The induced long-term effect found in the two
European studies was only found for rapidly growing firms in the United States. Therefore, we conclude that the initial conditions are more favorable for larger start-ups and new locations and plants of 


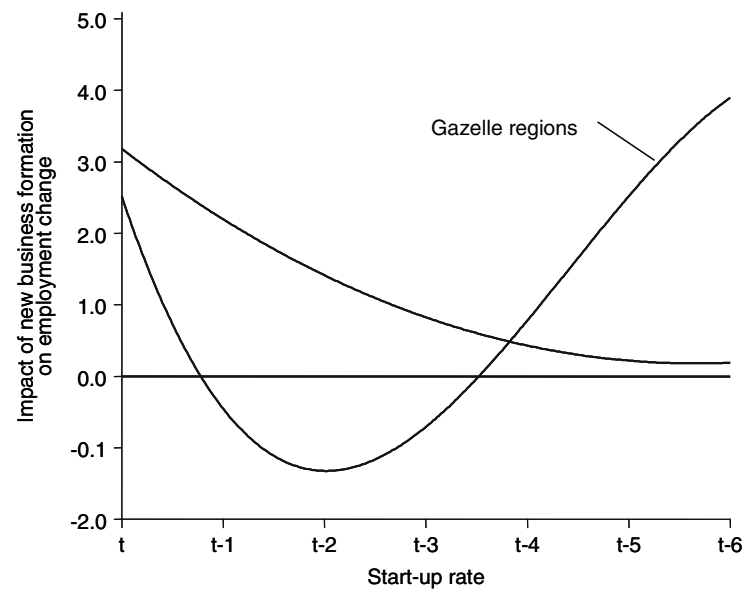

Fig. 6 Employment effects-start-ups of firms 20-499 employees: gazelle regions vs. other regions

existing firms. Future research should also differentiate between new independent firms and new locations of existing firms in combination with a distinction of entry size.

\section{References}

Acs, Z. J., \& Armington, C. (2006). Entrepreneurship, geography, and American economic growth. New York: Cambridge University Press.

Acs, Z. J., \& Armington, C. (2004). Employment growth and entrepreneurial activity in cities. Regional Studies, 39(8), 911-927.

Acs, Z. J., \& Armington, C. (1998). Longitudinal establishment and enterprise microdata LEEM documentation, Center for Economic Studies, U. S. Bureau of the Census, CES, pp. 98-9.

Acs, Z. J., Armington, C., \& Zhang, T. (2007). The determinants of new-firm survival across regional economies. Annals of Regional Science (forthcoming).

Acs, Z. J., \& Audretsch, D. B. (1989a). Small-firm entry in U. S. manufacturing. Economica, 56(2), 255-256.

Acs, Z. J., \& Audretsch, D. B. (1989b). Births and firm size. Southern Economic Journal, 56(2), 467-475.

Acs, Z. J., \& Storey, D. J. (2004). Introduction: Entrepreneurship and economic development. Regional Studies, 38(8), 871-877.

Armington, C., \& Acs, Z. J. (2004). Job creation and persistence in service and manufacturing. Journal of Evolutionary Economics, 14, 305-329.

Audretsch, D. B. (1995). Innovation and industry innovation. Cambridge, Mass: MIT Press.

Birch, D. L. (1981). Who creates jobs? The Public Interest, 65, 3-14.

Brock, W. A., \& Evans, D. S. (1989). Small business economics. Small Business Economics, 1(1), 7-20.
Bruderl, J., P. Preisendorfer, \& R. Ziegler (1992). Survival chances of newly founded business organizations. American Sociological Review, 57(2), 227-242.

Camer, C., \& Lovallo, D. (1999). Overconfidence and excess entry: An experimental approach. American Economic Review, 89, 306-318.

Caves, R. E. (1998). Industrial organization and new findings on the turnover and mobility of firms. Journal of Economic Literature, 36(4), 1947-1982.

Davis, S. J., \& Haltiwanger, J. (1992). Gross job creation, gross job destruction, and employment reallocation. Quarterly Journal of Economics, 107(3), 819-863.

Davis, S. J., \& Haltiwanger, J. (1999). Gross job flows. In O. Ashenfelter, \& D. Card (Eds.), Handbook of labor economics, Volumes 3 and 4. Amsterdam, Netherlands: Elsevier Science.

Davis, S. J., Haltiwanger, J., \& Schuh, S. (1996a). Job creation and destruction. Cambridge Mass: MIT Press.

Davis, S. J., Haltiwanger, J., \& Schuh, S. (1996b). Small business and job creation: Dissecting the myth and reassessing the facts. Small Business Economics, 8(4), 297-315.

Dopfer, K. (1995). special issue, Global economic evolution: Knowledge variety and diffusion in economic growth and development. Journal of Evolutionary Economics, 5(3), 181-339.

Dunne, T., Roberts, M. J., \& Samuelson, L. (1989). The growth and failure of U. S. manufacturing plants. Quarterly Journal of Economics, 104(4), 671-698.

Evans, D. S. (1987). Tests of alternative theories of firm growth. Journal of Political Economy, 95(4), 657-654.

Florida, R. (2002). The rise of the creative class. New York: Basic Books.

Foster, L., Haltiwanger, J., \& Krizan, C. J. (2006). Market selection, reallocation, and restructuring in the U.S. retail trade sector in the 1990s. Review of Economics and Statistics, 88(4), 748-758.

Fritsch, M., \& Mueller, P. (2004). The effects of new business formation on regional development over time. Regional Studies, 38(8), 961-975.

Fritsch, M., \& Mueller, P. (2007). The effect of new business formation on regional development over time: The case of Germany. Small Business Economics, doi: 10.1007/ s11187-007-9067-9, this issue.

Greene (2003). Econometric analysis (5th ed.). Prentice Hall, Upper Saddle River, NJ.

Haltiwanger, J. (2006). Entrepreneurship and job growth, Paper presented at the Ewing Marion Kauffman - Max Planck Conference on Entrepreneurship and Economic Growth, May 2006, Munich Germany.

Hopenhayn, H. A. (1992). Entry, exit and firm dynamics in long run equilibrium. Econometrica, 60(5), 1127-1150.

Jarmin, R. S., \& Miranda, J. (2002). The longitudinal business database. CES Working Paper 02-17.

Jovanovic, B. (1982). Selection and the evolution of industry. Econometrica, 50(3), 649-670.

Katsoulacos, Y. (1994). Special issue, evolutionary and neoclassical perspectives on market structure and economic growth. Evolutionary Economics, 4(2), 151-271.

Klepper, S. (2002). The capabilities of new firms and the evolution of the U. S. auto industry. Industry and Corporate Change, 11, 645-666. 
Klomp, L., \& Thurik, R. A. (1999). Job flows of firms in traditional services. In Z. Acs, et al. (Eds.), Entrepreneurship, small and medium sized enterprises and the macroeconomy. Cambridge, UK: Cambridge University Press.

Lambson, V. E. (1991). Industry evolution with sunk costs and uncertain market conditions. International Journal of Industrial Organization, 9(2), 171-198.

Lee, S. Y., Florida, R., \& Acs, Z. J. (2004). Creativity and entrepreneurship: A regional analysis of new firm formation. Regional Studies, 38(8), 879-891.

Lucas, R. E. Jr. (1978). On the size distribution of business firms. Bell Journal of Economics, 9(2), 508-523.

Lucas, R. E. Jr., \& Prescott, E. C. (1971). Investment under uncertainty. Econometrica, 39(5), 659-681.

Moen, J. (2005). Is Mobility of Technical Personnel a Source of R\&D Spillovers'? Journal of Labor Economics, 23, 81-114.

Mueller, P., Stel, A. J., \& Storey, D. J. (2007). The effects of new firm formation on regional development over time: The case of Great Britain. Small Business Economics, doi: $10.1007 / \mathrm{s} 11187-007-9056-\mathrm{z}$, this issue.
Pakes, A., \& Richard, E. (1995). Markov-perfect industry dynamics. A framework for empirical work. Review of Economic Studies, 62(1), 53-82.

Pakes, A., \& Richard, E. (1998). Empirical implications of alternative models of firm dynamics. Journal of Economic Theory, 79, 1-45.

Pakes, A., \& Nitzan, S. (1983). Optimum contracts for research personnel, research employment, and the establishment of "rival' enterprises. Journal of Labor Economics, 1, 345365.

van Stel, A. J., \& Storey, D. J. (2004). The link between firm births and job creation: Is there a Upas tree effect? Regional Studies, 38(8), 893-909.

van Stel, A. J., \& Suddle, K. (2007). The impact of new firm formation on regional development in the Netherlands. Small Business Economics, doi: 10.1007/11187-0079054-1, this issue.

Sutton, J. (1997). Gibrat's legacy. Journal of Economic Literature, 35(1), 40-59. 